\title{
Perbaikan Metode Kerja Untuk Meningkatkan Produktivitas Kerja Operator Pada Stasiun Pengemasan Di CV. Mie Sohun Ichlas
}

\author{
Ismu Kusumanto ${ }^{1}$, Yoga Perdana ${ }^{2}$ \\ 1,2 Jurusan Teknik Industri, Fakultas Sains dan Teknologi, UIN Sultan Syarif Kasim Riau \\ J1. HR. Soebrantas No. 155 Simpang Baru, Panam, Pekanbaru, 28293 \\ Email: ismu_uin@yahoo.co.id, yogaperdana0794@yahoo.com
}

\begin{abstract}
ABSTRAK
Perkembangan dunia industri manufaktur dan jasa semakin meningkat pesat dari waktu ke waktu sehingga setiap pelaku industri harus siap berkompetisi dengan kompetitornya. Oleh karena itu masalah dan faktor-faktor yang berhubungan dengan peningkatan produktivitas semakin menonjol dan perlu untuk diteliti. Penelitian ini dilaksanakan di industri pembuatan mie sohun "CV. Mie Sohun Ichlas Pekanbaru". Pada penelitian ini yang diteliti yaitu metode kerja dan layout kerja operator. kemudian dilakukan perbaikan dengan menerapkan metode 5S pada lingkungan kerja. Setelah dilakukan pengolahan data dan pembahasan terhadap data pengukuran waktu pengemasan, analisis metode $5 \mathrm{~S}$ pada layout baik sebelum dan sesudah perbaikan, dan jumlah output standar masing-masing operator pada stasiun tersebut. Ternyata jumlah output standar pada kondisi sesudah perbaikan mengalami peningkatan dibandingkan kondisi sebelum perbaikan. Hal ini terbukti dengan indeks produktivitas yang meningkat dari sebelum perbaikan dilakukan dimana indeks produktivitas sebelum perbaikan operator stasiun pengemasan 1 dan 2 adalah sebesar 94,1\% dan 92,6\%, sedangkan indeks produktivitas layout kerja sesudah perbaikan masing-masing operator stasiun pengemasan 1 dan 2 adalah sebesar 104,5\% dan 100,9\%. Oleh karena itu, bisa dikatakan bahwa metode 5S dan micromotion study telah membawa efek yang baik bagi perbaikan metode kerja dengan menghilangkan gerakan kerja yang tidak efektif dan menata lingkungan kerja agar lebih tertata rapi dan bersih sehingga produktivitas kerja operator dapat meningkat.
\end{abstract}

Kata Kunci: Produktivitas, 5S (Seiri, Seiton, Seiso, Seiketsu, dan Shtsuke), Micromotion Study, Perbaikan Metode Kerja

\section{Pendahuluan}

Pada era globalisasi dan pasar bebas, perkembangan industri baik manufaktur maupun jasa terus-menerus mengalami peningkatan sehingga menuntut pelaku industri harus siap berkompetisi serta selalu siap meningkatkan kinerja serta produktivitasnya. Masalah peningkatan produktifitas tidak dapat terlepas dari faktor manusia beserta lingkungan kerjanya yang dapat diamati, diteliti, dianalisa, dan diperbaiki. Hal ini dilakukan guna mendapatkan alternative cara kerja yang lebih baik, efektif, dan efisien serta di dukung juga oleh lingkungan kerjanya yang lebih baik. Salah satu usaha yang dapat dilakukan untuk mendapatkan metode kerja operator yang lebih baik yaitu dengan menggunakan metode $5 \mathrm{~S}$ dan micromotion study.

Dalam usaha mendapatkan metode kerja yang baik perlu dilakukan analisis terhadap metode kerja yang digunakan seperti perbaikan metode kerja yang selama ini digunakan yang mungkin belum menghasilkan produktifitas yang optimal Mengamati pekerjaan yang sedang berlangsung, hal yang sudah pasti terlihat adalah gerakan-gerakan yang membentuk kerja tersebut. Studi gerakan umumnya diklasifikasikan ke dalam dua macam studi, yaitu visual motion study dan micromotion study. Visual motion study umumnya lebih sering diaplikasikan karena dianggap jauh lebih ekonomis, sedangkan penelitian yang dilakukan sekarang ini adalah dengan menggunakan micromotion study walaupun biaya lebih mahal tetapi dapat digunakan untuk mengamati pekerjaan yang berlangsung lebih cepat dan berulang-ulang secara detail, karena dipergunakan peralatan khusus (movie camera) untuk merekam gerakan-gerakan yang berlangsung. Penelitian ini akan dilaksanakan di industri pembuatan mie sohun "CV. Mie Sohun Ichlas Pekanbaru". CV. Mie Sohun Ichlas adalah salah satu perusahaan yang bergerak dalam bidang pembuatan mie sohun dan tepung hunkwee dengan bahan dasarnya berasal dari tepung sagu. Perusahaan Mie Sohun Ichlas terletak di jalan Siak 2 (Palas-Rumbai). Adapun penerapan sistem produksi pada perusahaan ini adalah dengan menggunakan sistem produksi make to stock.

Saat ini CV. Mie Sohun Ichlas memiliki 2 stasiun pengemasan diantaranya yaitu stasiun pengemasan 1 menggunakan plastik Gambar 1 (a), dan stasiun pengemasan 2 menggunakan kertas padi Gambar 1 (b). Berdasarkan hasil observasi yang 
telah dilakukan pada stasiun pengemasan 1 dan 2 dapat ditemukan kurangnya penataan, baik terhadap lingkungan kerja maupun penataan terhadap peralatan-peralatan kerja operator serta banyaknya terdapat sisa-sisa mie sohun yang berserakan disekitar lingkungan kerja operator. Hal ini akan berdampak pada ketidaknyamanan pekerja serta penurunan terhadap tingkat produktivitas kerja dari operator. Seperti yang terlihat pada Gambar 1 berikut:

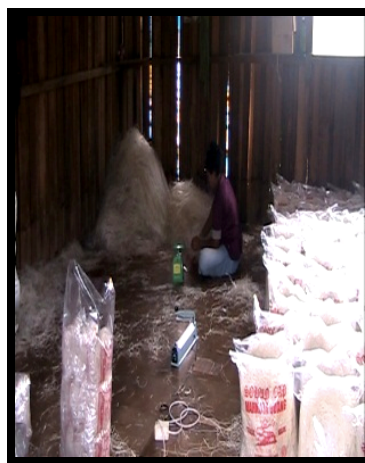

(a)

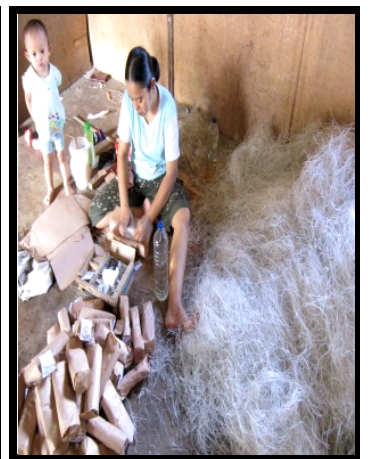

(b)
Gambar 1. Kondisi Lingkungan Kerja, a). Stasiun Pengemasan 1, dan b). Stasiun Pengemasan 2

Pada Gambar 1 (a) memperlihatkan kondisi lingkungan kerja operator yang tidak rapi dan bersih, seperti ditemukannya mie sohun yang berserakan dimana-mana. Tidak teraturnya penataan terhadap lingkungan kerja operator pengemasan ini akan dapat mempengaruhi lama waktu pencarian peralatan kerja dan akan menimbulkan idle time. selain itu, dampak lainnya akan menyebabkan ruang pekerja terbatas, banyaknya mie yang akan terbuang (waste), serta menimbulkan ketidaknyamanan terhadap pekerjanya. Sedangkan pada gambar 1 (b) memperlihatkan kondisi dimana terdapatnya penumpukan alat-alat kerja yang tidak tertata dengan baik, serta lingkungan kerja operator yang tidak rapi dan bersih. Selain itu, juga ditemukan sampah bekas bungkusan plastik permen dan sampah bekas botol minuman yang berada disekitar area kerja operator. Hal ini akan menimbulkan ketidaknyamanan kerja operator, serta akan memperlama waktu pengerjaan yang dilakukan oleh operator.

Selain masalah lingkungan kerja operator yang tidak tertata rapi dan bersih, cara kerja yang selama ini dilakukan oleh operator tidak efektif. Hal ini terlihat dari peletakan alat-alat kerja yang digunakan oleh operator, terletak berjauhan serta tidak tertata dengan baik (Lihat Gambar 1) sehingga hal ini akan menyebabkan menurunnya tingkat produktivitas kerja dari operator sebagaimana yang dapat dilihat pada Tabel 1 berikut:
Tabel 1 Rasio Perbandingan Indeks Produktivitas Awal Operator Stasiun Pengemasan

\begin{tabular}{|c|c|c|c|c|}
\hline No. & Operator & $\begin{array}{c}\text { Jam } \\
\text { Kerja } \\
\text { (Jam) }\end{array}$ & $\begin{array}{c}\text { Output } \\
\text { Perhari } \\
\text { (Bungkus) }\end{array}$ & $\begin{array}{c}\text { Indeks } \\
\text { Produktivitas }\end{array}$ \\
\hline \multicolumn{5}{|c|}{ Stasiun Pengemasan 1 } \\
\hline 1. & $\begin{array}{c}\text { Operator } \\
1\end{array}$ & 9 & 820 & 91,1 \\
\hline 2. & $\begin{array}{c}\text { Operator } \\
2\end{array}$ & 9 & 835 & 92,8 \\
\hline 3. & $\begin{array}{c}\text { Operator } \\
3\end{array}$ & 9 & 855 & 95 \\
\hline Stasiun Pengemasan 2 & \multicolumn{2}{|c|}{7} \\
\hline 1. & $\begin{array}{c}\text { Operator } \\
1\end{array}$ & 8 & 720 & 90 \\
\hline 2. & $\begin{array}{c}\text { Operator } \\
2\end{array}$ & 8 & 755 & 94,4 \\
\hline 3. & $\begin{array}{c}\text { Operator } \\
3\end{array}$ & 8 & 744 & 93,8 \\
\hline
\end{tabular}

(Sumber: CV. Mie Sohun Ichlas, 2016)

Tabel 1 memperlihatkan bahwa adanya perbedaan yang signifikan terhadap pencapaian indeks produktivitas kerja dari setiap operator pada stasiun pengemasan. Perbedaan tingkat produktivitas kerja ini diakibatkan oleh lingkungan kerja dari operator yang tidak tertata dengan rapi dan bersih serta adanya kegiatan yang sifatnya diluar dari bagian pekerjaan operator, sehingga hal tersebut akan mempengaruhi lama waktu penyelesaian yang akan dilakukan oleh operator. Berikut adalah grafik rasio perbandingan antara indeks produktivitas kerja operator pada stasiun pengemasan.



Gambar 2. Rasio Perbandingan Produktivitas Awal Operator Pengemasan

Berdasarkan Gambar 2 diatas, terlihat perbedaan yang signifikan terhadap tingkat pencapaian produktivitas kerja dari operator pada stasiun pengemasan. Hal ini sangat dipengaruhi oleh penggunaan metode kerja yang selama ini tidak efektif yang telah diterapan oleh operator.

Berdasarkan deskripsi yang telah dijelaskan pada paragraf sebelumnya, diperlukan adanya perbaikan terhadap lingkungan kerja beserta metode kerja operator pada stasiun pengemasan di perusahaan tersebut. Salah satu cara untuk memperbaiki permasalahan tersebut adalah dengan 
menerapkan metode 5S dan Micromotion Study dengan tujuan terciptanya lingkungan kerja yang lebih bersih dan rapi serta menciptakan metode kerja yang lebih baik dengan menghilangkan gerakan kerja operator yang tidak efektif sehingga dengan demikian diharapakan dapat meningkatkan produktifitas kerja operator.

\section{Tinjauan Pustaka}

\section{Metode 5S}

Metode 5S merupakan tahap untuk mengatur kondisi tempat kerja yang berdampak terhadap efisiensi kerja, produktifitas kerja, kualitas kerja, dan keselamatan kerja. Salah satu cara menciptakan suasana kerja yang nyaman dan aman adalah perusahaan menerapkan sikap kerja 5S. Lingkungan kerja yang sebelumnya kurang nyaman bagi pekerja dapat diperbaiki dan disusun dengan program $5 \mathrm{~S}$ supaya karyawan memiliki budaya kerja baik, sehingga kualitas produk yang dihasilkan sesuai standar perusahaan dan internasional (Jahja dalam Septaviani, 2012 dalam Putri, 2014).

Dalam bahasa Indonesia lima langkah pemeliharaan tempat kerja ini disebut sebagai $5 \mathrm{R}$ (Ringkas, Rapi, Resik, Rawat, dan Rajin). Kampanye 5R (di Indonesia) (Imai, 1998):

1. Ringkas

Membedakan antara yang diperlukan dan tak diperlukan di perusahaan dan menyingkirkan yang tak diperlukan. Membuat tempat kerja ringkas, yang hanya menampung barang-barang yang diperlukan saja.

2. Rapi

Menata semua barang yang ada setelah ringkas, dengan pola yang teratur dan tertib.

3. Resik

menjaga kondisi mesin yang siap pakai dan dalam keadaan bersih. Menciptakan kondisi tempat dan lingkungan kerja yang bersih.

4. Rawat

Memperluas konsep kebersihan pada diri pribadi dan terus menerus mempraktekkan tiga langkah terdahulu. Selalu berusaha menjaga keadaan yang sudah baik melalui standar.

5. Rajin

Membangun disiplin diri pribadi dan membiasakan diri untuk menerapkan 5R melalui norma kerja dan standarisasi.

Takashi Osada dalam Prihadi Waluyo (2011: 3-4) dalam Jamaluddin, 2014 menjelaskan bahwa manfaat yang akan diperoleh bila menerapkan metode 5S ini antara lain:
1. Menyediakan Tempat Kerja yang Menyenangkan
2. Membantu Untuk Mengefisienkan Pekerjaan
3. Memperkecil Kecelakaan Kerja

4. Membimbing Pada Kualitas Produk yang Lebih Baik dan Peningkatan Produktivitas.

\section{Ekonomi Gerakan}

Untuk mendapatkan hasil kerja yang baik, diperlukan perancangan sistem kerja yang baik, hal ini penting karena sistem kerja harus dirancang sedemikian rupa sehingga dapat memungkinkan dilakukan gerakan-gerakan ekonomis. Maka diperlukan prinsip-prinsip ekonomi gerakan (Sutalaksana, 1979).

1. Prinsip-prinsip ekonomi gerakan dihubungkan dengan tubuh manusia dan gerakan-gerakannya.

a. Kedua tangan sebaiknya memulai dengan mengakhiri gerakan pada saaat yang sama.

b. Kedua tangan sebaiknya tidak menganggur pada saaat yang sama kecuali pada waktu istirahat.

c. Gerakan kedua tangan akan lebih mudah jika satu terhadap yang lainnya simetris dan berlawanan arah.

d. Gerakan tangan atau badan sebaiknya dihemat. Yaitu dengan menggerakkan tangan atau bagian badan yang diperlukan saja untuk melakukan pekerjaan dengan sebaik-baiknya.

e. Sebaiknya pekerja dapat memanfaatkan momentum sehingga dapat membantu pekerjaannya.

f. Gerakan yang patah-patah, banyak perubahan arah akan memperlambat gerakan tersebut.

g. Gerakan balistik akan lebih cepat, menyenangkan, dan lebih teliti daripada gerakan yang dkendalikan.

h. Pekerjaan sebaiknya dirancang semudahmudahnya, dan jika memungkinkan irama kerja harus mengikuti irama yang alamiah bagi si pekerja.

i. Usahakan sedikit menggunakan mata.

2. Prinsip-prinsip ekonomi gerakan dihubungkan dengan pengaturan tata letak tempat kerja.

a. Sebaiknya diusahakan agar bahan dan peralatan mempunyai tempat yang tetap.

b. Tempatkan bahan-bahan dan peralatan di tempat yang mudah, cepat, enak untuk dicapai.

c. Tempat penyimpanan bahan yang akan dikerjakan sebaiknya memanfaaatkan prinsip gaya berat sehingga bahan yang akan dipakai selalu tersedia di tempat yang dekat untuk diambil.

d. Sebaiknya untuk menyalurkan objek yang sudah selesai dirancang dirancang mekanismenya yang baik. 
e. Bahan-bahan dan peralatan sebaiknya ditempatkan sedemikian rupa sehingga gerakan-gerakan dapat dilakukan dengan uruta-urutan terbaik.

f. Tinggi tempat kerja dan kursi sebaiknya sedemikian rupa sehingga alternatif berdiri atau duduk dalam menghadapi pekerjaan merupakan hal yang menyenangkan.

g. Tipe tinggi kursi sedemikian rupa sehingga yang mendudukinya bersikap baik.

h. Tata letak dan perancangan sebaiknya diatur sedemikian rupa sehingga dapat membentuk kondisi yang baik untuk penglihatan.

3. Prinsip-prinsip ekonomi gerakan dihubungkan dengan perancangan peralatan .

a. Sebaiknya tangan dapat dibebaskan dari semua pekerjaan bila penggunaan dari perkakas pembantu atau alat yang dapat digerakkan dengan kaki dapat ditingkatkan.

b. Sebaiknya peralatan dirancang sedemikian rupa mempunyai lebih dari satu kegunaan.

c. Peralatan sebaiknya dirancang sedemikian rupa sehingga memudahkan dalam pemegangan .

d. Bila setiap jari tangan melakukan gerakan gerakan sendiri-sendiri, beban yang didistribusikan pada jari harus sesuai dengan kekuatan masing-masing jari.

e. Roda tenaga, palang, dan peralatan yang sejenis dengan itu sebaiknya diatur sedemikian rupa sehingga beban dapat melayaninya dengan posisi yang baik dan dengan tenaga yang minimum.

\section{Gerakan Fundamental (Therbligs)}

Mempermudah penganalisaan terhadap gerakan-gerakan yang akan dipelajari terlebih dahulu gerakan-gerakan dasar yang membentuk kerja tersebut. Guna melaksanakan maksud ini, maka Frank dan Lilian Gilberth telah berhasil menciptakan simbol/kode dari gerakan-gerakan dasar kerja yang dikenal dengan nama THERBLIGH. Disini menguraikan gerakangerakan dasar kerja ke dalam 17 gerakan dasar Therbligh (Wignjosoebroto, 2008).

Secara garis besar masing-masing Therblighs tersebut dapat didefinisikan sebagai berikut :
a. Mencari (Search)
b. Memilih (Select)
c. Memegang (Grasp)
d. Menjangkau/Membawa Tanpa Beban (Transport Empty)
e. Membawa Dengan Beban (Transport Loaded)
f. Memegang Untuk Memakai (Hold)
g. Melepas (Release Load)
h. Mengarahkan (Position)
i. Mengarahkan Awal (Pre-Position)
j. Memeriksa (Inspection)
k. Merakit (Assemble)
1. Mengurai Rakit (Dissembly)
m. Memakai (Use)

 (Avoidable Delay)
p. Merencanakan (Plan)
q. Istirahat untuk menghilangkan lelah (Rest to
Overcome Fatique)

\section{Peta Tangan Kiri dan Tangan Kanan}

Peta Tangan Kiri dan Tangan Kanan adalah peta kerja setempat yang bermanfaat untuk menganalisa gerakan tangan manusia di dalam melakukan pekerjaan-pekerjaan yang bersifat manual. Peta ini akan menggambarkan semua gerakan maupun delay yang terjadi yang dilakukan oleh tangan kanan maupun kiri secara mendetail Dengan menganalisa detail gerakan yang terjadi maka langkah-langkah perbaikan bisa diusulkan. Pembuatan peta operator ini baru terasa bermanfaat apabila gerakan yang dianalisa tersebut terjadi berulang-ulang (repetitive) dan dilakukan secara manual. Dari analisa yang dibuat maka pola gerakan tangan yang dianggap tidak efisien dan bertentangan dengan prinsip-prinsip ekonomi gerakan (motion economy) bisa diusulkan untuk diperbaiki. Demikian pula akan diharapkan terjadi keseimbangan gerakan yang dilakukan oleh tangan kanan dan tangan kiri, sehingga siklus kerja akan berlangsung dengan lancar dalam ritme gerakan yang lebih baik yang akhirnya mamapu memberikan delays maupun operator fatique yang minimum (Wignjosoebroto, 2008).

\section{Micromotion Study}

Mengamati suatu pekerjaan yang sedang berlangsung hal ini sudah pasti terlihat adalah adanya suatu gerakan-gerakan yang membentuk kerja tersebut. Gerakan-gerakan yang dilakukan oleh seorang pekerja adakalanya pula sudah tepat atau sudah sesuai dengan gerakan-gerakan yangdiperlukan, tetapi adakalanya pula seorang pekerja melakukan gerakan yang tidak perlu / biasa disebut gerakan-gerakan yang tidak efektif. Dalam menganalisa gerakan kerja sering dijumpai kesulitan dalam menentukan batas-batas suatu elemen Therbligh dengan elemen lainnya karena waktu gerakan yang terlalu singkat. sehingga sangat sulit untuk diamati secara visual. Perekaman atas gerakan-gerakan kerja dengan video dan segala perlengkapannya akan dapat mengatasi persoalan ini. Disini hasil bisa diputar ulang kalau perlu dengan kecepatan lambat sehingga analisa gerakan kerja bisa dilakukan lebih teliti. Dengan bantuan 
sejenis jam khusus (micro chronometer), maka waktu setiap elemen Therbligh maupun perpindahan dari suatu elemen ke elemen lain yang diukur. Aktifitas micromotion study mengharuskan setiap gerakan yang ada secara detail dan memberi kemungkinan-kemungkinan analisa setiap gerakan yang ada setiap detail dan kemungkinan analisa setiap gerakan yang ada secara lebih baik dibandingkan dengan visual motion study. Langkahlangkah yang dikerjakan dalam micromotion study ini terdiri dari (Wignjosoebroto, 2008):

a. Merekam gerakan-gerakan kerja dari suatu siklus kerja dengan menaruh jam besar (micro chronometer) di belakang operator yang diamati.

b. Gambar film akan menjadi rekaman yang permanen yang bisa dianalisa setiap saat dan berulang-ulang sesuai dengan yang dikehendaki.

c. Membuat kesimpulan dari analisa gerakan yang telah diamati dari rekaman film dan menggambarkannya dalam peta SIMO (Simultaneous Motion Chart) yang menunjukkan gerakan-gerakan tangan kanan dan tangan kiri. Tujuan pokok penggambaran peta ini adalah mencoba membuat keseimbangan gerak kerja antara lain tangan kanan atau tangan kiri di dalam menyelesaikan suatu aktifitas (misalnya dalam suatu proses merakit).

d. Menetapkan alternatif gerakan kerja yang lebih baik dengan jalan memperbaiki metode kerja yang ada sesuai dengan prinsip-prinsip ekonomi gerakan (motion economy).

Dengan demikian jelas bahwa dari aktifitas micromotion study diharapkan akan mampu membantu di dalam usaha mencari alternatif metode kerja yang lebih baik untuk menyelesaikan suatu pekerjaan, sekaligus mengetahui waktu dan tiap-tiap gerakan kerja tersebut.

\section{Metode Penelitian}

Metodologi penelitian merupakan deskripsi dari seluruh rangkaian kegiatan yang dilaksanakan selama proses penelitian, yakni dari awal kegiatan sampai dengan akhir penelitian. Metodologi penelitian digunakan untuk mengarahkan serta mempermudah proses pemecahan masalah dan menganalisa hasil pengolahan melalui manajemen penelitian yang baik sehingga penelitian yang dilakukan dapat menjadi lebih berkualitas. Setiap tahapan dalam metodologi penelitian adalah bagian yang penting sehingga harus dilakukan dengan baik dan teliti.

Adapun uraian langkah-langkah penelitian tersebut adalah sebagai berikut.

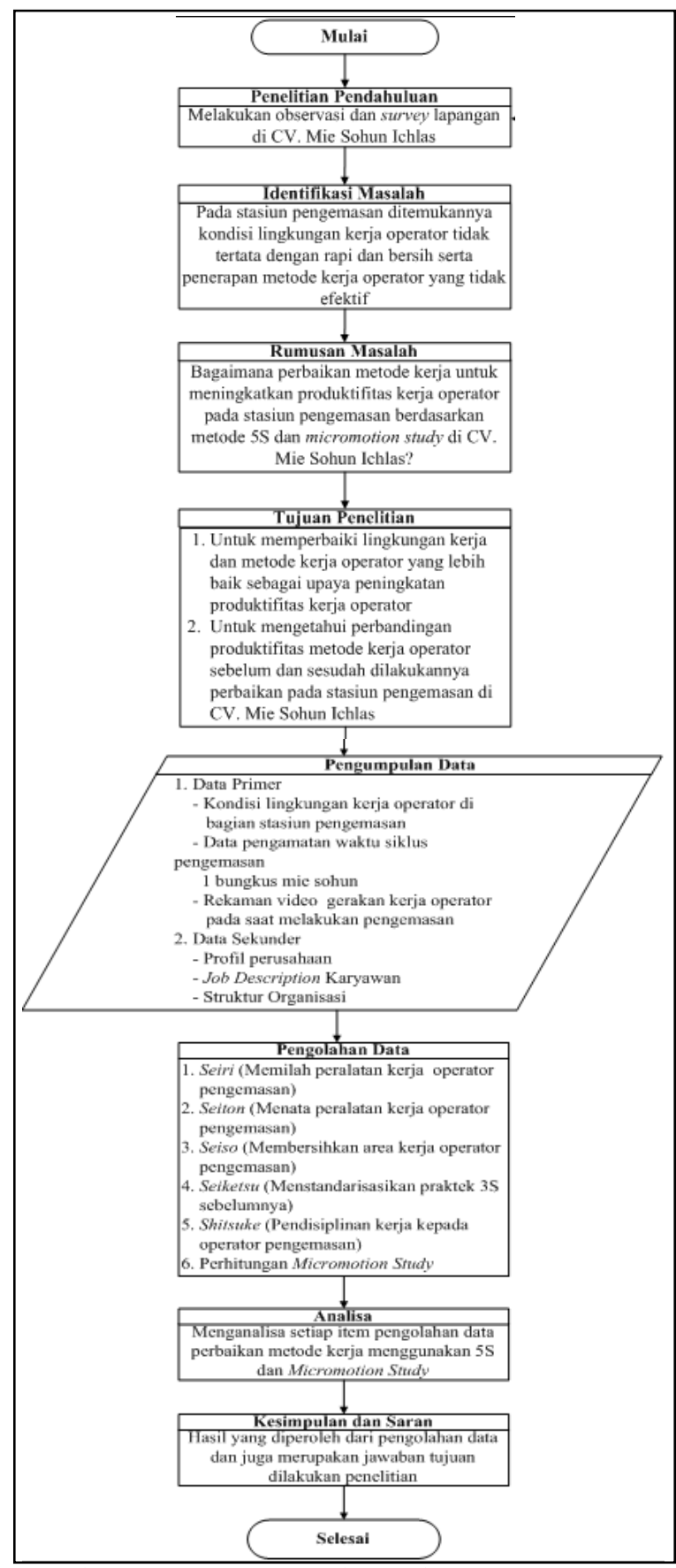

Gambar 3. Flowchart Metode Penelitian

\section{Hasil dan Pembahasan}

Pada hasil pembahasan dalam penelitian ini, diawali dengan evaluasi kondisi lingkungan kerja operator menggunakan metode 5S, kemudian dilanjutkan dengan analisa produktivitas operator menggunakan Micromotion Study. Adapun penjelasan masing-masing kondisi kerja operator sebelum dan sesudah perbaikan adalah sebagai berikut: 


\section{Sebelum Perbaikan Lingkungan dan Layout Kerja Operator Stasiun Pengemasan}

Tabel 2. Kondisi Kerja 5S Operator Stasiun Pengemasan Sebelum Perbaikan

\begin{tabular}{|c|c|c|}
\hline No. & $\begin{array}{c}\text { Metode } \\
5 S\end{array}$ & Keterangan \\
\hline 1. & Seiri & $\begin{array}{l}\text { 1. Tidak adanya tempat atau wadah } \\
\text { khusus yang memisahkan mie } \\
\text { sohun yang telah dibungkus dan } \\
\text { yang belum dibungkus pada area } \\
\text { kerja operator Gambar } 1 \text { (a) } \\
\text { 2. Peletakan peralatan kerja yang } \\
\text { bercampur dengan peralatan - } \\
\text { peralatan kerja lainnya Gambar } 1 \\
\text { (b) sehingga tidak jelas mana yang } \\
\text { diperlukan dan yang tidak } \\
\text { diperlukan. }\end{array}$ \\
\hline 2. & Seiton & $\begin{array}{l}\text { 1. Tumpukan mie sohun yang tidak } \\
\text { diletakkan pada wadah khusus } \\
\text { mengakibatkan lingkungan kerja } \\
\text { tidak nyaman sehingga } \\
\text { mengganggu kerja operator } \\
\text { Gambar 1 (a) } \\
\text { 2. Tidak adanya tempat khusus } \\
\text { terhadap penyusunan mie sohun } \\
\text { yang telah siap dikemas Gambar } 1 \\
\text { (b). } \\
\text { Tidak adanya keteraturan } \\
\text { pengelompokan alat kerja sesuai } \\
\text { kepentingannya. }\end{array}$ \\
\hline 3. & Seiso & $\begin{array}{l}\text { 1. Terdapatnya sapu pada tumpukan } \\
\text { mie sohun yang akan dikemas } \\
\text { Gambar } 1 \text { (a). } \\
\text { Adanya operator lain yang } \\
\text { menggunakan sandal pada area } \\
\text { kerja operator Gambar 1, } \\
\text { sehingga hal ini akan } \\
\text { mempengaruhi hieginisnya } \\
\text { produk mie yang akan dipasarkan } \\
\text { nantinya kepada konsumen. } \\
\text { 3. Terdapatnya sisa-sisa mie sohun } \\
\text { yang berserakan disepanjang area } \\
\text { kerja operator Gambar } 1 \text { (a). } \\
\text { 4. Terdapat sampah bungkusan plastik } \\
\text { serta sampah botol bekas yang } \\
\text { terdapat pada area kerja operator } \\
\text { Gambar 1 (b). }\end{array}$ \\
\hline 4. & Seiketsu & $\begin{array}{llr}\text { 1. } & \text { Kesadaran pekerja } & \text { untuk } \\
\text { mempertahankan budaya } & \text { kerja } \\
\text { seiri (Memilah), } & \text { seiton } \\
\text { (Merapikan), } & \text { seiso } \\
\text { (Membersihkan) secara terus - } & \text { menerus masih belum terlaksana } \\
\text { dan perlu diterapkan. }\end{array}$ \\
\hline 5. & Shitsuke & $\begin{array}{l}\text { 1. Disiplin pribadi pekerja mengenai } \\
\text { kebersihan dan kerapian dalam } \\
\text { bekerja perlu ditingkatkan. } \\
\text { 2. Penyuluhan terhadap akan } \\
\text { pentingnya kebersihan dan } \\
\text { kerapian terhadap peralatan dan } \\
\text { tempat kerja kepada pekerja masih } \\
\text { belum terlaksana. }\end{array}$ \\
\hline
\end{tabular}

(Sumber: Pengolahan Data, 2016)

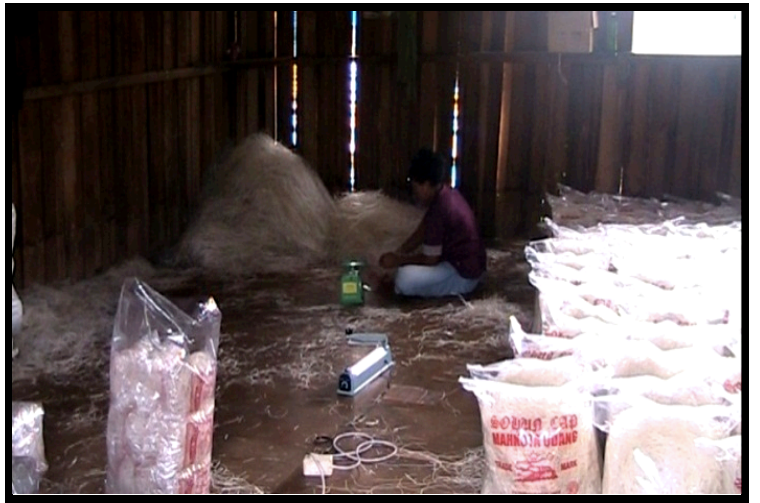

Gambar 4. Lingkungan Kerja Operator Stasiun Pengemasan 1

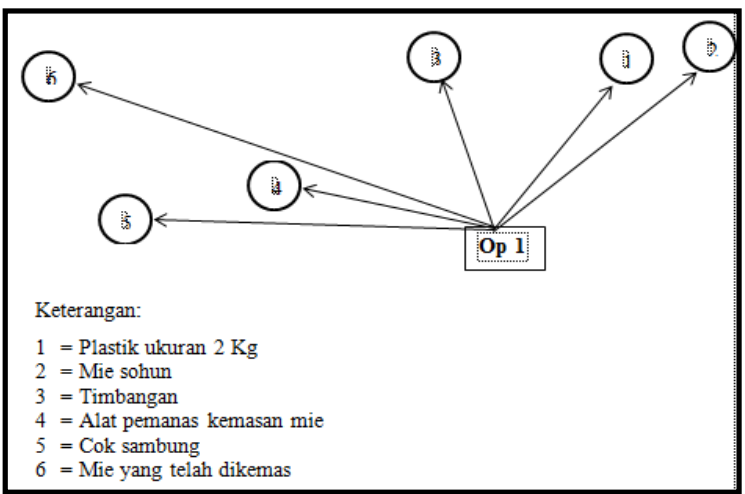

Gambar 5. Layout Kerja Operator Pengemasan 1

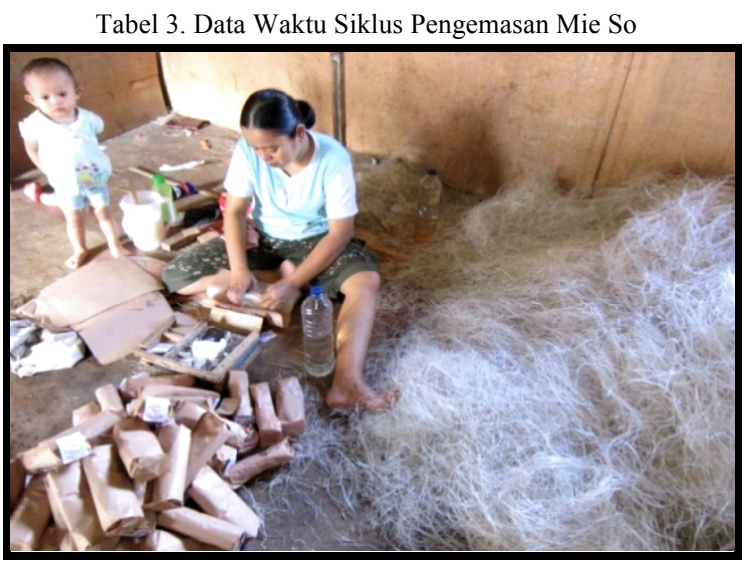

Gambar 6. Lingkungan Kerja Operator Pengemasan 2 




Gambar 7. Layout Kerja Operator Pengemasan 2

\begin{tabular}{|l|c|c|c|c|c|c|c|c|c|c|c|}
\hline \multirow{2}{*}{ Operator } & \multicolumn{8}{|c|}{ Waktu Siklus (Detik) } & Rata-rata \\
\cline { 2 - 11 } & $\boldsymbol{X}_{\boldsymbol{1}}$ & $\boldsymbol{X}_{\mathbf{2}}$ & $\boldsymbol{X}_{\mathbf{3}}$ & $\boldsymbol{X}_{\mathbf{4}}$ & $\boldsymbol{X}_{\mathbf{5}}$ & $\boldsymbol{X}_{\mathbf{6}}$ & $\boldsymbol{X}_{\mathbf{7}}$ & $\boldsymbol{X}_{\boldsymbol{8}}$ & $\boldsymbol{X}_{\mathbf{9}}$ & $\boldsymbol{X}_{\boldsymbol{1 0}}$ & \\
\hline $\begin{array}{l}\text { Stasiun } \\
\text { Pengemasan 1 }\end{array}$ & 29 & 28 & 26 & 28 & 29 & 27 & 28 & 25 & 27 & 26 & 27,3 \\
\hline $\begin{array}{l}\text { Stasiun } \\
\text { Pengemasan 2 }\end{array}$ & 30 & 31 & 36 & 38 & 32 & 32 & 35 & 33 & 36 & 33 & 33,6 \\
\hline
\end{tabular}

(Sumber: Pengolahan Data, 2016)

Dari Pengamatan waktu rata-rata pada layout kerja sebelum perbaikan masing-masing operator pengemasan 1 dan 2 adalah sebesar 27,3 detik dan 33,6 detik. Kemudian, rating performance masingmasing operator stasiun pengemasan 1 dan 2 adalah sebesar $14 \%$ dan $11 \%$. Serta allowance selama 8 jam kerja operator stasiun pengemasan 1 dan 2 adalah sebesar $16,5 \%$.

Maka :

a. Operator Stasiun Pengemasan 1

$$
\begin{aligned}
\mathrm{Wn} & =\mathrm{Ws} \times \mathrm{P} \\
& =27,3 \text { detik } \times(1+0,14) \\
& =31,1 \text { detik } \\
\mathrm{Wb} & =\mathrm{Wn} \times \frac{100 \%}{100 \%-\text { Allowance }} \\
\mathrm{Wb} & =31,1 \text { Detik } \times \frac{100 \%}{100 \%-16,5 \%}
\end{aligned}
$$

$\mathrm{Wb}=37,2$ detik per bungkus atau 0,010 jam per bungkus

Output Standar $=\frac{\text { Lama Jam Kerja Operator }}{\mathrm{Ws}}$

Output Standar $=\frac{8 \text { Jam }}{0,010 \text { Jam Per Bungkus }}$

Output Standar $=800$ Bungkus

Indeks Produktivitas

$$
=\frac{\text { Produktivitas Setelah Perbaikan }}{\text { Produktivitas Sebelum Perbaikan }} \times 100 \%
$$

Indeks Produktivitas $=\frac{800}{850} \times 100 \%$

Indeks Produktivitas $=94,1 \%$

b. Operator Stasiun Pengemasan 2
$\mathrm{Wn}=\mathrm{Ws} \times \mathrm{P}$

$$
=33,6 \text { detik } \times(1+0,11)
$$

$=37,3$ detik

$\mathrm{Wb}=\mathrm{Wn} \times \frac{100 \%}{100 \%-\text { Allowance }}$

$\mathrm{Wb}=37,3$ Detik $\mathrm{x} \frac{100 \%}{100 \%-16,5 \%}$

$\mathrm{Wb}=44,6$ detik per bungkus atau 0,012 jam per bungkus

Output Standar $=\frac{\text { Lama Jam Kerja Operator }}{\text { Ws }}$

Output Standar $=\frac{8 \text { Jam }}{0,012 \text { Jam Per Bungkus }}$

Output Standar $=667$ Bungkus

Indeks Produktivitas

$=\frac{\text { Produktivitas Setelah Perbaikan }}{\text { Produktivitas Sebelum Perbaikan }} \times 100 \%$

Indeks Produktivitas $=\frac{667}{720} \times 100 \%$

Indeks Produktivitas $=92,6 \%$

4.2 Sesudah Perbaikan Lingkungan dan Layout Kerja Operator Stasiun Pengemasan

Tabel 4. Kondisi Sikap Kerja 5S Sesudah Perbaikan

\begin{tabular}{|l|l|l|}
\hline No. & Metode 5S & \multicolumn{1}{|c|}{ Keterangan } \\
\hline & & $\begin{array}{l}\text { Memisahkan dan mengelompokkan } \\
\text { bahan atau barang yang diperlukan } \\
\text { menurut kepentingannya, sisa-sisa mie } \\
\text { sohun yang berserakan dilantai } \\
\text { ditempatkan terpisah dari mie sohun yang } \\
\text { sudah dikemas sehingga tidak bercampur } \\
\text { baur. }\end{array}$ \\
\hline
\end{tabular}




\begin{tabular}{|c|c|c|}
\hline & & $\begin{array}{l}\text { 2. Memisahkan barang yang diperlukan } \\
\text { dengan barang yang tidak diperlukan, } \\
\text { barang yang tidak diperlukan di area } \\
\text { kerja operator seperti plastik bekas dan } \\
\text { botol bekas diletakkan dari tempat kerja. }\end{array}$ \\
\hline 2. & Seiton & 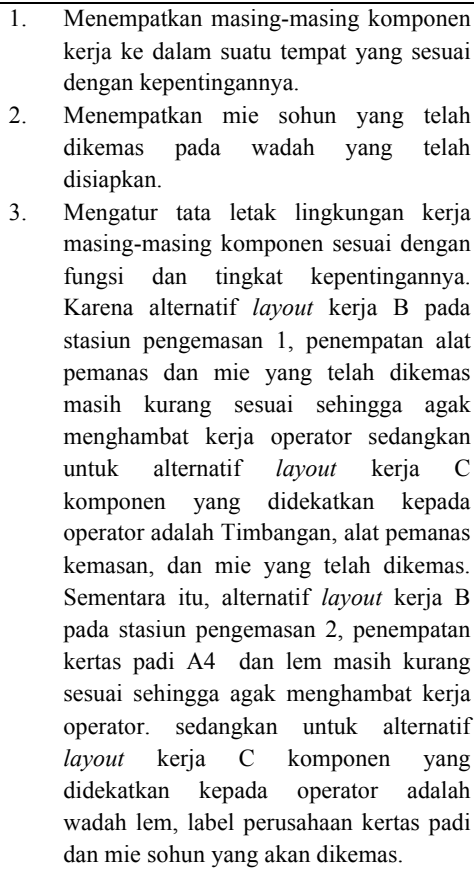 \\
\hline 3. & Seiso & $\begin{array}{l}\text { 1. Membuang dan membersihkan semua } \\
\text { debu serta sampah pada area kerja } \\
\text { operator ke tempat yang telah disediakan. } \\
\text { 2. Membiasakan diri menyediakan waktu } \\
\text { untuk membersihkan peralatan dan } \\
\text { tempat kerja. }\end{array}$ \\
\hline 4. & Seiketsu & $\begin{array}{llr}\text { 1. } & \text { Kesadaran pekerja } & \text { untuk } \\
\text { mempertahankan seiri, seiton, dan seiso } \\
\text { secara terus-menerus sudah mulai } \\
\text { terbentuk karena sudah mulai terbiasa } \\
\text { dengan metode dan cara kerja yang baru. }\end{array}$ \\
\hline 5. & Shitsuke & $\begin{array}{l}\text { 1. Disiplin pribadi karyawan mengenai } \\
\text { kebersihan dan kerapian dalam bekerja } \\
\text { masih perlu ditingkatkan. } \\
\text { 2. } \\
\text { Penyuluhan terhadap akan pentingnya } \\
\text { kebersihan dan kebersihan terhadap } \\
\text { peralatan dan tempat kerja karyawan } \\
\text { mulai menunjukkan hasilnya. }\end{array}$ \\
\hline
\end{tabular}

(Sumber: Pengolahan Data, 2016)

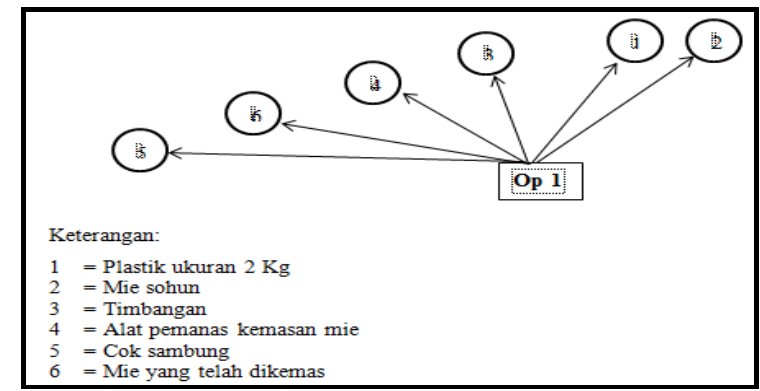

Gambar 8. Layout Kerja Operator Pengemasan 1

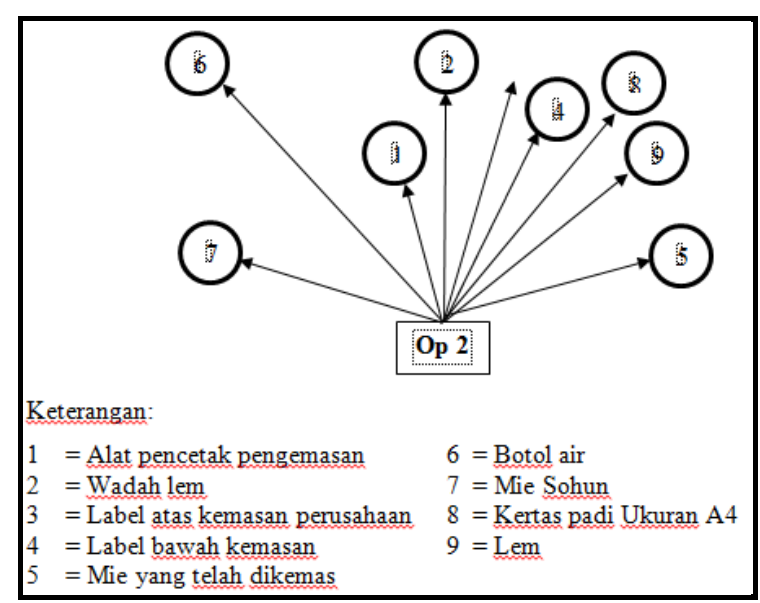

Gambar 9. Layout Kerja Operator Pengemasan 2

Tabel 5. Data Waktu Siklus Pengemasan Mie Sohun

\begin{tabular}{|l|c|c|c|c|c|c|c|c|c|c|c|}
\hline \multirow{2}{*}{ Operator } & \multicolumn{10}{|c|}{ Waktu Siklus (Detik) } & \multicolumn{2}{c|}{$\begin{array}{c}\text { Rata- } \\
\text { rata }\end{array}$} \\
\cline { 2 - 12 } & $\boldsymbol{X}_{\boldsymbol{1}}$ & $\boldsymbol{X}_{\mathbf{2}}$ & $\boldsymbol{X}_{\mathbf{3}}$ & $\boldsymbol{X}_{\mathbf{4}}$ & $\boldsymbol{X}_{\mathbf{5}}$ & $\boldsymbol{X}_{\mathbf{6}}$ & $\boldsymbol{X}_{\mathbf{7}}$ & $\boldsymbol{X}_{\boldsymbol{8}}$ & $\boldsymbol{X}_{\mathbf{9}}$ & $\boldsymbol{X}_{\boldsymbol{1 0}}$ & \\
\hline $\begin{array}{l}\text { Stasiun } \\
\text { Pengemasan 1 }\end{array}$ & 25 & 23 & 22 & 24 & 25 & 22 & 24 & 25 & 23 & 22 & 23,5 \\
\hline $\begin{array}{l}\text { Stasiun } \\
\text { Pengemasan 2 }\end{array}$ & 30 & 29 & 31 & 30 & 29 & 31 & 30 & 29 & 31 & 30 & 30 \\
\hline
\end{tabular}

(Sumber: Pengolahan Data, 2016)

Dari Pengamatan waktu rata-rata pada layout kerja sebelum perbaikan masing-masing operator pengemasan 1 dan 2 adalah sebesar 23,5 detik dan 30 detik. Kemudian, rating performance masingmasing operator stasiun pengemasan 1 dan 2 adalah 
sebesar $16 \%$ dan $13 \%$. Serta allowance selama 8 jam kerja operator stasiun pengemasan 1 dan 2 adalah sebesar $15,5 \%$.

Maka :

a. Operator Stasiun Pengemasan 1

$$
\begin{aligned}
& \begin{aligned}
\mathrm{Wn} & =\mathrm{Ws} \times \mathrm{P} \\
& =23,5 \text { detik } \times(1+0,16) \\
& =27,3 \text { detik }
\end{aligned} \\
& \begin{aligned}
\mathrm{Wb} & =\mathrm{Wn} \times \frac{100 \%}{100 \%-\text { Allowance }}
\end{aligned} \\
& \begin{aligned}
& \mathrm{Wb}=27,3 \text { Detik } \times \frac{100 \%}{100 \%-15,5 \%} \\
& \mathrm{~Wb}=32,3 \text { detik per bungkus atau } 0,009 \text { jam } \\
& \text { per bungkus }
\end{aligned} \\
& \text { Output Standar }=\frac{\text { Lama Jam Kerja Operator }}{\mathrm{Ws}} \\
& \text { Output Standar }=\frac{8,009 \text { Jam Per Bungkus }}{\text { Output Standar }=888 \text { Bungkus }} \\
& \text { Indeks Produktivitas } \\
& \text { Produktivitas Setelah Perbaikan } \\
& \text { Produktivitas Sebelum Perbaikan } 100 \% \\
& \text { Indeks Produktivitas }=\frac{888}{850} \times 100 \% \\
& \text { Indeks Produktivitas }=104,5 \%
\end{aligned}
$$

b. Operator Stasiun Pengemasan 2

$$
\begin{aligned}
& \begin{aligned}
\mathrm{Wn} & =\text { Ws } \mathrm{P} \\
& =30 \text { detik } \times(1+0,13) \\
& =33,9 \text { detik }
\end{aligned} \\
& \begin{aligned}
\mathrm{Wb} & =\mathrm{Wn} \times \frac{100 \%}{100 \%-\text { Allowance }}
\end{aligned} \\
& \begin{aligned}
& \mathrm{Wb}=33,9 \text { Detik } \times \frac{100 \%}{100 \%-15,5 \%} \\
& \mathrm{~Wb}=40,1 \text { detik per bungkus atau } 0,012 \text { jam } \\
& \text { per bungkus }
\end{aligned} \\
& \text { Output Standar }=\frac{\text { Lama Jam Kerja Operator }}{\mathrm{Ws}} \\
& \text { Output Standar }=\frac{8 \text { Jam }}{0,011 \text { Jam Per Bungkus }} \\
& \text { Output Standar }=727 \text { Bungkus } \\
& \text { Indeks Produktivitas } \\
& \text { Produktivitas Setelah Perbaikan } \\
& \text { Produktivitas Sebelum Perbaikan } 100 \% \\
& \text { Indeks Produktivitas }=\frac{727}{720} \times 100 \% \\
& \text { Indeks Produktivitas }=100,9 \%
\end{aligned}
$$

\section{Kesimpulan}

Berdasarkan hasil penelitian yang dilakukan di CV. Mie Sohun Ichlas, maka secara umum dapat disimpulkan sebagai berikut:

1. Perbaikan lingkungan kerja dan metode kerja operator dilakukan berdasarkan kondisi pada saat sebelum dan sesudah dilakukannya perbaikan. Perbaikan dilakukan dengan menggunakan metode 5S (Seiri, Seiton, Seiso, Seiketsu, dan Shitsuke) untuk menata lingkungan dan layout kerja kedua operator stasiun pengemasan tersebut, kemudian dianalisa menggunakan micromtion study. Pada pengolahan sebelum perbaikan diketahui layout dan lingkungan kerja masing-masing operator kurang tertata rapi dan bersih, sehingga mengakibatkan banyaknya gerakan yang tidak perlu seperti mencari-cari barang atau komponen kerja yang akan berakibat memperlama waktu penyelesaian pengemasan mie yang tentunya akan mempengaruhi jumlah produk mie yang mampu dikemas per harinya.

2. Setelah dilakukannya perbaikan dengan memberikan waktu standar penyelesaian kerja yang lebih singkat dan jumlah output standar yang lebih tinggi daripada layout sebelum dilakukanya perbaikan. Hal ini berarti perbaikan yang dilakukan memberikan hasil yang baik karena berhasil meningkatkan produktivitas kerja masing-masing operator stasiun pengemasan di perusahaan tersebut. Hal ini terlihat dari perhitungan indeks produktivitas kerja masing-masing operator, operator stasiun pengemasan 1 yang awalnya sebesar 94,1\% menjadi 104,5\%. Sedangkan untuk operator stasiun pengemasan 2 yang awalnya sebesar $92,6 \%$ menjadi $100,9 \%$.

\section{Daftar Pustaka}

Imai, M. "Gemba Kaizen: Pendekatan Akal Sehat, Berbiaya Rendah Pada Manajemen". Penerjemah: Kristianto Jahja. Cetakan Kedua. Jakarta: Pustaka Binaman Pressindo. 1998.

Jamaluddin, E. Perbedaan Lama Waktu Pencarian Peralatan Tangan Sebelum Dan Sesudah Penerapan Metode 5R (Ringkas, Rapi, Resik, Rawat, dan Rajin) Pada Bengkel Umum Sepeda Motor Di Kecamatan Ungaran Barat. Skripsi: Universitas Negeri Semarang. 2014.

Osada, T. "Sikap Kerja 5S: Seiri Pemilahan, Seiton Penataan, Seiso Pembersihan, Seiketsu Pemantapan, Shitsuke Pembiasaan". Penerjemah: Dra. Mariani Gandamihardja. 
Cetakan Keempat. Jakarta: Penerbit PPM. 2002.

Putri, D. I. Analisis Penerapan 5R (Ringkas, Rapi, Resik, Rawat, dan Rajin) Di Bengkel Utama PT. Bukit Asam (Persero) Tbk Unit Pertambangan Tanjung Enim. Manuskrip Skripsi: Universitas Sriwijaya Palembang. 2014.

Sutalaksana, I.,Z., Anggawisastra, R., dan Tjakraatmadja, J.,H. "Teknik Tata Cara Kerja". Bandung: Penerbit Jurusan Teknik Industri Institut Teknologi Bandung. 1979.

Wignjosoebroto, S. "Ergonomi Studi Gerak dan Waktu, Teknik Analisis Untuk Peningkatan Produktivitas Kerja". Edisi Pertama, Cetakan Keempat. Surabaya: Penerbit Guna Widya. 2008 

Jurnal Hasil Penelitian dan Karya Ilmiah dalam Bidang Teknik Industri 